(for example, Turks), Hungarians cannot be viewed as a Celtic population. Thus, we show a relatively unexpected high frequency of the $\mathrm{C} 282 \mathrm{Y}$ point mutation in Hungarians which, to some extent, argues against a Celtic origin of this mutation.

The help of Éva Bakos and Pavol Ivanyi is gratefully acknowledged. This work was supported by grants from the National Ministry of Social Welfare and Health (ETT 211/1996), OMFB (5958), and OTKA (F0 17270). AT is a recipient of the "Magyary Zoltán" scholarship.

ATTILA TORDAI HAJNALKA ANDRIKOVICS LAJOS KALMÁR KATALIN RAJCZY MÁRIA PÉNZES BALÁZS SARKADI National Institute of Haematology and Immunology, and Research Group of the Hungarian Academy of Sciences, Budapest, Hungary

IZABEL KLEIN ANDRÁS VÁRADI

Institute of Enzymology of the Hungarian Academy of Sciences, Budapest, Hungary

1 Merryweather-Clarke AT, Pointon, J, Shearman $\mathrm{D}$, Robson, KJH. Global prevalence of putative haemochromatosis mutations. $\mathcal{f}$ Med Genet 1997;34:275-8.

2 Feder JN, Gnirke A, Thomas W, et al. A novel MHC class I-like gene is mutated in patients with hereditary hemochromatosis. Nat Genet 1996;13:399-408.

3 Smith BN, Kantrowitz W, Grace ND, et al. Prevalence of hereditary hemochromatosis in a Massachusetts corporation: is Celtic origin a risk factor? Hepatology 1997;25:1439-46.

4 Chang JG, Liu TC, Lin SF. Rapid diagnosis of the HLA-H gene Cys 282 Tyr mutation in hemochromatosis by polymerase chain reaction - a very rare mutation in the Chinese tion - a very rare mutation in the

5 Martinez PA, Jeanjean P, Masmejean C, et al. Simple and rapid detection of the newly described mutations in the HLA-H gene. Blood 1997;89:1835-6.

6 Roth MP, Giraldo P, Hariti G, et al. Absence of the hemochromatosis gene Cys282Tyr mutation in three ethnic groups from Algeria tion in three ethnic groups from Algeria 1997;46:222-5.

7 Czeizel A, Benkmann HG, Goedde HW, eds. Genetics of the Hungarian population. Budapest: Akadémiai Kiadó, Berlin: Springer-Verlag, 1991:307-34.

\section{Hypoplastic left heart in cerebrocostomandibular syndrome}

Cerebrocostomandibular syndrome (CCMS) is a rare disorder characterised by severe micrognathia and posterior "rib gap" defects. Since the first report of this condition by Smith et al in 1966, 50 cases have been reported. ${ }^{2}$ Severe micrognathia and radiographic evidence of posterior rib gap defects have been constant features. We report a female infant with typical features of CCMS who also had hypoplastic left heart syndrome, which caused her death. A cardiac lesion has been identified only once before in CCMS, in an infant with a large ventricular septal defect. $^{3}$

The female proband was the third child of healthy, unrelated parents. Her father and mother were of French and Mauritian descent, respectively. Neither parent had any clinical or radiographic evidence of mild

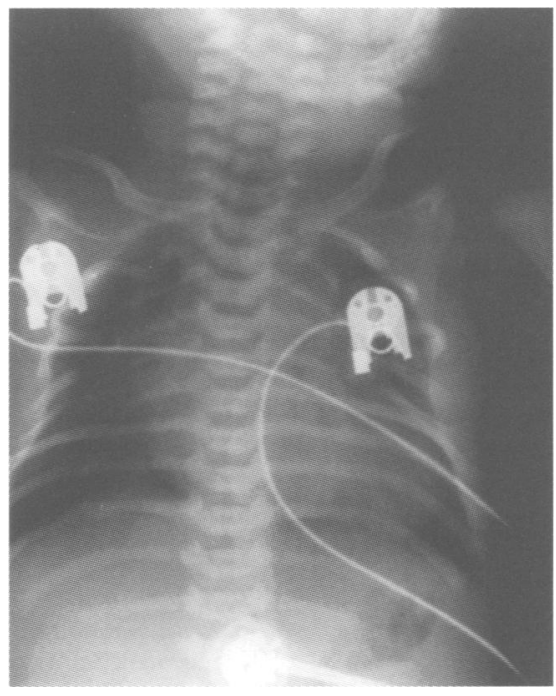

Figure 1 Chest radiograph showing multiple rib gaps.

CCMS. The pregnancy was uncomplicated, with spontaneous vertex delivery at 37 weeks' gestation. Birth weight was $2200 \mathrm{~g}$, length 45 $\mathrm{cm}$, and occipitofrontal circumference $31 \mathrm{~cm}$ (all less than the 3 rd centile for gestational age). Features noted at birth included severe microretrognathia, glossoptosis, and a midline cleft of the soft palate, all of which contributed to early upper airway obstruction and moderate respiratory distress. Initial examination was otherwise normal.

A chest radiograph (fig 1) showed multiple posterior rib gaps involving the second to sixth ribs on the right and the second to fifth ribs on the left. The gap in the right second rib resembled a pseudarthrosis. There were 11 pairs of ribs. Cranial ultrasound was normal. Karyotype on peripheral blood lymphocyte culture was $46, \mathrm{XX}$.

On the third day of life a cardiac murmur was noted. Echocardiography showed findings consistent with hypoplastic left heart syndrome. Given the poor prognosis associated with hypoplastic left heart syndrome, active management was withdrawn and she died aged 8 days. Her parents declined necropsy.

This is the second reported case of a cardiac anomaly in CCMS, and the first in which hypoplastic left heart syndrome is described. A potential mechanism to account for the concurrence of hypoplastic left heart and CCMS is unclear. Vascular insufficiency has been postulated in the causation of hypoplastic left heart syndrome, but there is no evidence to support a disturbance in normal rib morphology on this basis. Embryologically, the heart is derived from lateral plate mesoderm and the ribs from paraxial mesoderm. Mandibular deficiency is considered to be the result of a defect in the ventral portion of the first branchial arch secondary to defective neural crest cell migration or proliferation. CCMS and hypoplastic left heart syndrome in our patient may have occurred together as part of a developmental field defect. Alternatively, an underlying basic defect in a developmental transcription control or signalling gene is possible. The CCMS phenotype should be expanded to include cardiac malformations even though this finding is uncommon.

EDIN KIRK

LESLEY ADES

Departments of Clinical Genetics, and Paediatrics and Child Health, Royal Alexandra Hospital for Children Hawkesbury Road, Westmead, NSW 2145, Australia

1 Smith DW, Theiler K, Schachenmann G Rib-gap defect with micrognathia, malformed Rib-gap defect with micrognathia, malformed tracheal cartilages and redundant skin: a new

2 Plötz FB, van Essen AJ, Bosschaart AN, Bos AP Plötz FB, van Essen AJ, Bosschaart AN, Bos AP. Med Genet 1996;62:286-92.

3 Kuhn JP, Lee SB, Jockin H, Wieder W. Cerebrocosto-mandibular syndrome: a case with cardiac anomaly. F Pediatr 1975;86:243-5.

\section{Another dystonia}

I read the Syndrome of the Month article on the dystonias by Jarman and Walker with great interest. ${ }^{1}$ This is a difficult clinical subject to study and the move to a molecular genetic classification is to be applauded. Accordingly I would like to draw attention to another form of dystonia which has been mapped to the short arm of the X chromosome between DX528 and DXS365. ${ }^{23}$

The dystonia is manifest mainly in the hands. The onset can be recognised in childhood by an odd positioning for some voluntary movements such as holding a pencil'; this has been called "fisting" by the family. More obvious dystonic movements develop in adolescence and these progress slowly over the years. The hands of the oldest affected subject, now aged 68, are severely disabled and he needs to be dressed and fed. This man also has dysarthria.

The other prominent and important feature of this syndrome is mental retardation of mild to moderate degree, more often the latter. The heterozygote carriers do not seem to be affected.

The syndrome is quite well known in medical genetics publications. ${ }^{45}$ It has been given two gene symbols, PRTS $^{3}$ and MRXS $1,{ }^{4}$ and is listed in the McKusick catalogue (MIM 309510). It was first reported 10 years ago in one family in Australia but so far no other cases have come to light. It is conceivable that it is a private syndrome with the mutation occurring in this family alone, but I believe it more likely that there are others with the same disorder which have just not been recognised. Part of the reason may be that the neurologists are not familiar with this form of dystonia.

M W PARTINGTON Hunter Genetics, PO Box 84, Waratah, NSW 2298, Australia

1 Jarman PR, Walker TT. The dystonias. $f \mathrm{Med}$ Genet 1998;35:314-18.

2 Partington MW, Mulley JC, Sutherland GR, Hockey A, Thode A, Turner G. X-linked mental retardation with dystonic movements of the hands. Am $₹$ Med Genet 1988;30:251-62.

3 Gedeon A, Partington MW, Mulley J. X-linked mental retardation with dystonic movements of the hands (PRTS ): revisited. Am $\mathcal{F}$ Med Genet 1994;51:565-8.

4 Glass IA. X linked mental retardation. $7 \mathrm{Med}$ Genet 1991;28:361-71.

5 Lubs HA, Chiurazzi P, Arena JF, Schwartz C,Tranebjaerg L, Neri G. XLMR genes: update 1996. Am $\mathcal{F}$ Med Genet 1996;64:147-57. 